\title{
Disclaimer
}

This report was prepared as an account of work sponsored by an agency of the United States Government. Neither the United States Government nor any agency thereof, nor any of their employees, makes any warranty, express or implied, or assumes any legal liability or responsibility for the accuracy, completeness, or usefulness of any information, apparatus, product, or process disclosed, or represents that its use would not infringe privately owned rights. Reference herein to any specific commercial product, process, or service by trade name, trademark, manufacturer, or otherwise does not necessarily constitute or imply its endorsement, recommendation, or favoring by the United States Government or any agency thereof. The views and opinions of authors expressed herein do not necessarily state or reflect those of the United States Government or any agency thereof. 
WSRC-RP- $-92-672$

DE93 007975

\section{Replacement Power Facility Site Selection Report ${ }^{(U)}$}

L. D. Wike, G. L. Toole, and W. L. Specht

Westinghouse Savannah River Company

Savannah River Site

Aiken, SC 29808

Prepared for the U. S. Department of Energy under contract No. DE-ACOYg-895SRi 8035

DISTRIRUTION OF THIS DOCUMENT IS UNLIMITED 


\title{
Replacement Power Facility Site Selection Report
}

\author{
L. D. Wike \\ G. L. Toole \\ W. L. Specht
}

\section{Executive Summary}

The Savannah River Site (SRS) has proposed the construction of a Replacement Power Facility (RPF) to supplement and replace existing sources of steam and possibly electricity to support site operations. One component of the overall project development is the identification and evaluation of locations on the SRS that would be suitable for the construction of such a facility.

An RPF Site Selection Team was identified that included representatives from three divisions of Westinghouse Savannah River Company, and two branches of DOE Savannah River Field Office. The task that was identified was to evaluate potential sites for placement of a $350 \mathrm{MW}$ fossil-fueled steam/electiic plant, conduct preliminary evaluations of potential impacts, and make recommendations conceming preferred sites. An initial screening process was applied to the areas within the SRS boundary that were unsuitable for construction of such a facility. The initial screening criteria that were applied were primarily environmental factors (e.g., high-quality wetlands or streams, endangered species sites, etc.), but also included avoidance of areas that are known candidates for large production facilities that might be located at SRS in the future and areas that currently have committed/restricted uses. This initial screening resulted in the identification of nine candidate sites for further evaluation.

The ninc candidate sites were evaluated by subject experts in each technical area and rated for a variety of engineering and environmental criteria. Engineering evaluations largely focused on the impacts (i.e., project size) of supplying connecting services (e.g., steam, rail, water etc) to the candidate sites. Both cost and environmental impact evaluations of the utility tie-ins were evaluated. Candidate sites for placement of the RPF were evaluated for ecological factors including potential wetland, terrestrial, and surface water impacts.

Of the nine sites that were evaluated, only two sites were clearly inferior to the other sites. The remaining seven sites represented a relatively small range of difference (12 points on a 100 point scale). Although no attempt was made to determine the magnitude of difference that might be considered 'significant', it is not considered pragmatic to pursue further characterization on all of the remaining sites. Because Sites 5 and 9, Site 9 southeast of D Area and Site 5 northwest of P Area near the intersections of SRS Roads 7 and $F$, differed by only a half point, an analysis of robustness based on scores in the most heavily weighted criteria was used to differentiate between these sites. This final analysis leads to the recommendation that Site 5 be considered as the preferred site and Site 9 as the alternate site. It is, however, recommended that further detailed characterization be pursued on both top sites , allow maximum flexibility and latitude in siting the facility in the event of any unforeseen difficulties arising with the preferred site.

\section{Introduction}

The Department of Energy (DOE) has proposed the construction and operation of a Replacement Power Facility (RPF) for supplementing and replacing existing sources of steam and possibly electricity at the Savannah River Site (SRS). DOE is preparing an Environmental Impact Statement (EIS) for this project. As part of the impact analysis of the proposed action, the EIS will include a detailed description of the environment where the RPF will be constructed. This description must be specific to the recommended site at SRS, which contains more than 300 square miles of land including streams, lakes, impoundments, wetlands, and upland areas. A formal site-selection process was designed and implemented to identify the preferred RPF site.

Site selection is essentially a decision that must incorporate objectives and considerations that are applicable to a specific project or facility. The procedure described in the following sections provides a technically sound determination of differences and similarities among potential sites and a justification for their numeric scoring. The information presented in this report is considered a screening-level analysis using existing data and the best professional judgment of experts. Through this process, a smaller number of candidate sites are identified for the more detailed environmental and engineering evaluations that are 
needed to support National Environmental Protection Act (NEPA) zcquirements.

\section{Site-Selection Team}

The Department of Erergy Savannah River Field Office (SRFO) delegated the process of site selection to Westinghouse Savannah River Company (WSRC). A task team including representatives from three WSRC divisions and two SRFO branches was formed to ensure that relevant interests were considered in the selection and evaluation of candidate sites.
F. I. Black
DOE, SRFO
S. A. Danker
G. L. Toole
DOE, SRFO
J. P. Harmon
WSRC, SUD
J. B. Gladden
WSRC, EPD
WSRC, ESS
L. D. Wikc
H. E. Mackey, Jr.
V. A. Rogers
W. L. Specht
WSRC, ESS
WSRC, ESS
WSRC, ESS
WSRC, ESS

The site-sclection team was responsible for identifying categorics and criteria for site selection and evaluation and gathering r levant information to support the analyses. The team sought additional technical support for evaluation of specific topics. The folluwing experts provided additional technical support:
R. K. Aadland
K. G. Aylward
F. A. Brooks
J. S. Haselow
C. H. Hunter
R. P. Muschick
R. Roecher
D. E. Stcphenson
A. L. Stcive

\section{Facility Description}

While the cxact type of facility has not been determined, site evaluation for the RPF was conducted assuming the facility would be a fossil-fueled plant of approximately $350 \mathrm{MW}$ capacity. Although many fossil fuels will be considered (e.g., coal, oil, gas), the siting process assumed the facility would opcrate on pulverized coal with onsite disposal of coal ash. Using pulverized coal presents a problem with space. Such a facility would require approximately 60 cleared acres inside the facility fence for pratuction, administration, coal storage, and other support facilities. An additional 40 acres would be required during the life of the plant for two ash/sludge disposal basins (20-acres each). During construction these future ash-basin sites will be used as construction lay-down areas. Facilities powered by fuel other than pulverized coal will likely require considerably less area.

The control of atmospheric discharges from pulverizedcoal boilers has advanced such that oxides of nitrogen emission from the burning of bituminous coal can be reduced to comply with federal standards. Dry-scrubber technology has also advanced significantly such that $94 \%$ of potential sulfur-dioxide emissions are removed. Circulating fluidized bed boilers (CFB) yield comparable emissions.

Surface-water discharges will be substantially reduced. Thermal effluents will be controlled using a cooling tower. Potential wastewater pollution from coal-pile runoff, cooling tower blowdown, process service-water discharge, and wastewater-treatment system blowdown will be used to supply make-up water for the dry-scrubber process. These pollutants will be evaporated by the flue gas and discharged as water vapor. Approximately 2,500 gallons per day of treated water will be discharged from the facility, and this small volume of water discharge will comply with all discharge requirements. Consequently, receptor streams for process-, cooling-, and sanitary-water discharges are not a significant issue in siting this facility. Additional details of facility design, requirements, and emissions are contained in the draft Replacement Power Facility Capital and Life Cycle Cost Estimate (Ebasco, 1992).

\section{Site Configuration}

A typical coal-fired power plant configuration for a 350 MW plant includes the following specific components:

- powerhouse, boiler/turbine buildings

- auxiliary service building

- administration, warehouse, and maintenance building

- parking

- coal-storage facilities for a 30-day supply of coal

- rail track

- high-voltage switchyard

- cooling towers (wet, mechanical draft)

- flue-gas treatment facilities

- scrubber-support facilities:

- lime silos process liquid filter houses

- clarifiers

- slurry-preparation area

- sulfur-dioxide disposal facilities 
- two 20-acre ash/sludge basins, 20-feet deep (total 800-acre-feet disposal volume)

A typical configuration for these facilities is included in Appendix A. There is considerable flexibility in the placement of individual components of the RPF and exact positioning will be determined following more detailed, site-specific surveys.

\section{Identification of Potential Sites}

Initial screcning of SRS for potential locations suitable for the construction and operation of the RPF was based on the identification and application of exclusion criteria by the site-selection team. The exclusion criteria were defined as conditions that would result in unacceptable impacts to high-quality environmental resources or conditions that would provide unacceptable features for construction or operation of the facility. The following were selected as exclusion criteria.

\section{Threatened and Endangered Species}

SRS contains populations of many species listed by federal or state agencies as threatened, endangered, or of special concern. Areas of the site specifically excluded were those under management for bald eagle nesting areas, red-cockaded woodpecker management areas, and areas known to hisve rare plants. Other threatened and endangered species were considered only if potential work would disturb their habitats. For example, the shortnose sturgeon was not directly considered because upland development would not have a direct impact on its habitat in the Savannah River.

\section{Category 1 Wetlands and Unavoidable Impacts to Category 1 Streams}

Category 1 resources are defined as unique and irreplaceable on a national basis or in the ecoregion section (DOI, 1981). At SRS this definition would include many Carolina bays, cypress-tupelo swamps, red-cockaded woodpecker habitat, and areas where any species of concern may be found. Any area of the site containing high-quality wetlands or headwater streams that would be directly and unavoidably affected as a result of the construction or operation of the RPF were also not considered. These areas included much of the headwaters drainage of Upper Three Runs Creck and the majority of Carolina bays.

\section{National Environmental Research Park Sites}

SRS was the first designated National Environmental Research Park (NERP). There are numerous areas around the site set aside for ecological and environmental research and preservation (Hillestad and Bennett, 1982). These areas and nearby sites that would produce detrimental effects to the NERP sites were not considered as locations for the RPF.

\section{Reserved for Future Use}

Certain areas of SRS have been selected for specific future development. Sites conflicting with the New Production Reactor site, Nuclear Weapons Complex Reconfiguration site, or the new sanitary landfill were not considered for the RPF.

\section{Known Waste Sites}

Locations of known waste sites were rejected as sites for the RPF.

\section{0-Year Floodplain}

All areas within the 100-year floodplain were not considered for the RPF.

\section{Depth to Groundwater Less than 20 feet}

Areas of the site most likely to have very shallow groundwater were not considered.

Exclusion criteria were identified on the SRS site map where possible (Figure 1). By committee consensus, nine areas suitable for the RPF were identified (Figure 2). These sites were then subjected to comparative evaluation using the selection criteria.

\section{Site Descriptions}

Site $\mathbf{1}$ is located on a ridge between the Mill Creek and .ower Three Runs watersheds. Mill Creek is a high-quality tributary of Upper Three Runs Creek that has not been disturbed by SRS operations. Because of the exceptionally high quality of the stream and the potential for erosion and 
Figure 1. SRS Map Showing Exclusion Areas 


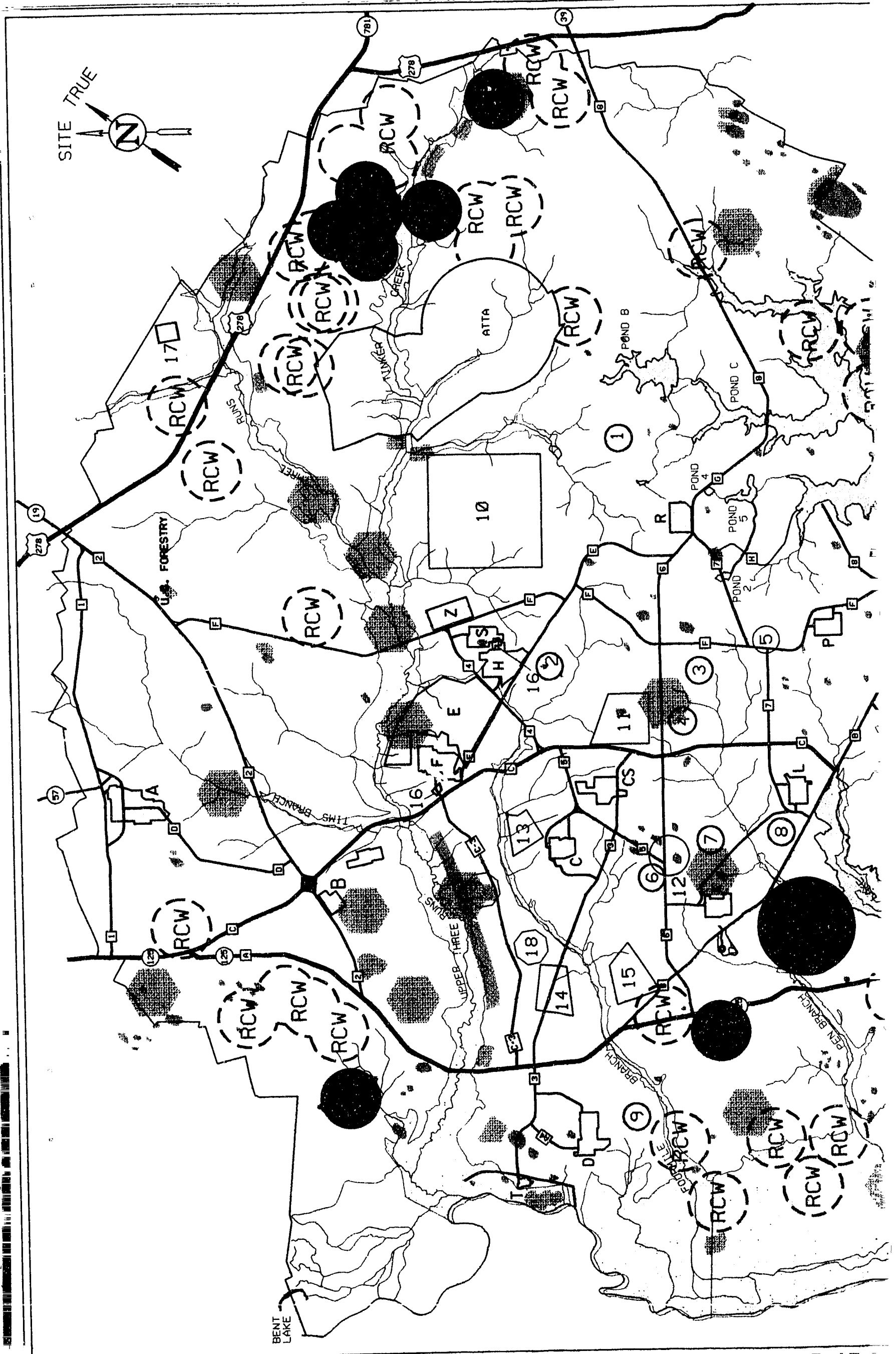


Figure 2. Location of the Nine Candidate Sites 


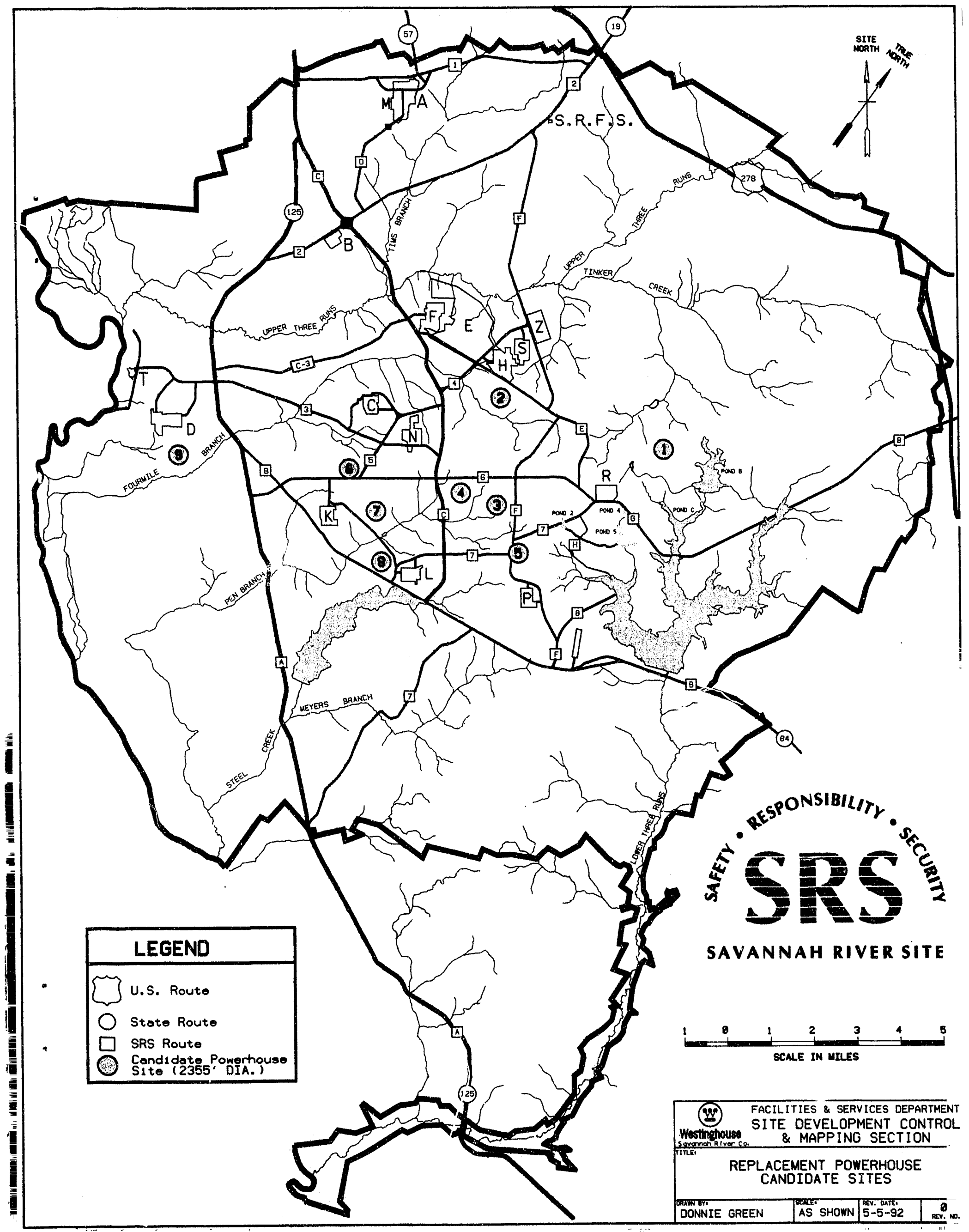


runoff during construction activities, this site had a relatively low rating for aquatic ecology. Vegetation consists primarily of stands of 25-year-old loblolly pine interspersed with small stands of mixed hardwoods. The site contains no wctlands but has the steepest slopes of any of the nine sites.

Site 2 is adjacent to the headwaters of Four Mile Creek. Although the headwaters of the creek have not been affected by SRS operations, the portions of the creek downstream from Site 2 have been perturbed by effluents from $\mathrm{F}$ and $\mathrm{H}$ areas and by seepage outcrops from the F- and H-Area seepage basins. Vegetation consists primarily of loblolly pine stands of two age classes. Approximately 50 acres of the sitc consists primarily of 10- to 12-year-old pines, while the remaining portion of nearly 100 acres has more mature pines that are about 25 years old. A small wetland depression of approximately one acre is in the southeast area of Site 2, but it is close to the edge of the site and can probably be avoided. Two small wetland areas of 16 and 8 acres are located north of the site along Road E, but no impacts to these wetlands are anticipated from the construc. tion or operation of the proposed facility.

Site $\mathbf{3}$ is located on a ridge between two headwater tributarics of Pen Branch. These tributaries provide a high-quality aquatic habitat and have not been impacted by past SRS operations. Much of Site 3 was used as a borrow arca about 3 years ago when the upper soil-layers were scraped and removed from most of the site. As a result, most of Site 3 has a poor quality soil that supports stands of stunted pines. This site contains the poorest quality of terrestrial habitat of any of the nine sites. Site 3 is almost surrounded by headwater-stream wetland areas, but no wetlands are on the site. Care would be needed during construction to ensure that these headwater wetlands are not tainted by construction runoff.

Site 4 also is located on a ridge between two headwater tributarics of Pen Branch. These tributaries have not been impacted by past SRS operations and provide high quality aquatic habitat. Vegetation consists mostly of even-aged stands of loblolly pines of two age classes. Approximately one third of the pines are 35 to 40 years old. The remaining stands of pines are approximately 25 years old and are located in the central portion ox the site. It appears that some thinning of the pirie stands was recently performed in this area. Sitc 4 contains approximately 10 acres of wetlands that would probably be impacted by the RPF. Vegetation in these wetland areas consists primarily of gum, water oak, and tupelo.
Site 5 is located on a ridge between the P-Reactor Canal and the Pen Branch watershed. The tributary of Pen Branch closest 10 Site 5 has not been perturbed by past SRS operations. However, since Site 5 is not located immediately adjacent to the tributary, impacts to the stream during construction are not anticipated if reasonable erosion and sedimentation control measures are employed. Approximately $60 \%$ of the site has pine stands that are about 40 years old, while most of the rernainder of the site supports pine stands that are about 20 years old. The site also supports several small pockets of hardwoods that are dominated by oaks and gum. There is a three to four acre wetland located along the southeast. perimeter of the site near the railroad tracks, but it is likely that encroachment on the wetland could be avoided, since it is located near the edge of the site.

Site 6 is located on a ridge top between a tributary of Four Mile Creek and the headwaters of the Indian Grave Branch tributary of Pen Branch. In the vicinity of Site 6, neither of these streams has been impacted by SRS operations, and therefore are considered to be high-quality headwater streams. Vegetation consists primarily of even-aged stands of loblolly pine. One small wetland of approximately two acres is located along the eastern perimeter of the site, but it probably can be avoided, since it is located along the edge of the site.

Site 7 is located between Indian Grave Branch and Pen Branch. In the vicinity of Site 7, neither of these streams has been impacted by SRS operations, and therefore are considered to be high-quality headwater streams. Approximately 40 acres of the site were recently clear cut and have not yet been replanted. The remainder of the site supports stands of 20- to 30-year-old loblolly pine. No wetlands are found within Site 7. Site 7 is part of a much larger tract (approximately 300 acres) of relatively flat, well-drained land. Because so few flat tracts of land of this size are still undeveloped on the SRS, and the RPF only requires a 100 -acre tract, it may be prudent to select another site for the RPF so that this larger tract can be reserved for a facility that would require a larger tract of land.

Site 8 is located on a hilltop between the Pen Branch and Steel Creek watersheds. The portion of Pen Branch that is adjacent to the site is a high-quality water resource, while Steel Creck has been impacted by past SRS activities. However, it is unlikely that any runoff from Site 8 would go to Pen Branch, because the east and south sides of the site are bounded by Roads 7 and $B$, which would intercept runoff to Steel Creek. Vegetation on the site consists mostly of pines, with a few small pockets of hardwoods at old home sites. 
Approximately 40 acres of site supports young stands of loblolly pine that are about 15 years old, while most of the remaining 60 acres supports trees that are about 40 years old and will probably be cut for saw timber in the near future. Site 8 contains no wetlands.

Site 9 is located in the Four Mile Creek watershed. The portion of Four Mile Creck closest to Site 9 was severely perturbed by thermal discharges from C Reactor, but has been recovering since 1985. Most of Site 9 was recently clear cut and provides poor quality terrestrial habitat at this time. The northeast corner of the site also contains about 15 acres of hardwoods. It is anticipated that the site will be replanted with pine seedlings in the near future. The site is adjacent to a small ( 5 acre) wetland that is east of Road 12.2, but impacts to the wetland can be avoided.

\section{Comparative Evaluation of Sites}

The nine candidate sites were compared using sl $\mathrm{ns}$ of criteria in the three major categories of ecology, erizencir ing, and others. Each category was weighted as a portion of a maximum score of 100 and each criterion was weighted within the categories (Table 1).

The critcria in ecology included terrestrial, wetland, and aquatic resources. Wetlands and aquatic resources each accounted for $36 \%$ of the - logy score while terrestrial resources contributed the remaining $16 \%$. Wetlands and aquatic resources were weighted higher than terrestrial resources because they are a more limited resource at SRS and are more sensitive to disturbance than the large areas of terrestrial forestry onsite. Candidate sites received higher marks when they encompassed little or no wetlands, were distant from high quality or previously unimpacted streams, and contained primarily uniform-age silviculture pine stands.

The remaining $12 \%$ of the ecology score was used for impacts involved with expansion of existing corridors and new corridor construction and was divided equally among terrestrial, wetlands, and aquatic impacts. Corridors were considered separately from the sites because they potentially contain large areas of resources. The corridor criteria were wcighted equally and not as heavily as the site criteria because much of the impact area would result from the expansion of existing corridors rather than extensive new development. This dictates the area in which the impacts occur, limiting the choices for avoiding higher quality resourcc areas and restricting the disturbance to areas that are already affected. Rather than including the relative sitewide value and abundance of terrestrial, wetland, and aquatic habitats, the corridor criteria for each of these were weighted equally to reflect the amount each would be impacted by the corridor expansion

The ecology category accounted for $48 \%$ of the total score for each site. Each site and its utility-interconnect corridor was evaluated for ecology criteria by members of the Environmental Sciences Section Ecology Group (ESS/EG) of SRTC using aerial photography and site maps. Evaluations were based on field visits, aerial photography, and soil maps. Criteria scores were determined by dividing the individual criterion's raw score (Appendix B) by the maximum possible for that criterion and multiplying it by the total possible points for the criterion. For example, Site 1 was awarded 11 of 16 possible points for terrestrial resources. The score for Site 1 would be eleven-sixteenths of $7.68(16 \%$ of 48$)$ or 5.28 points. Forty-eight points were possible for each site, and total scores were calculated by summing the criteria scores for each site.

The engincering category contributed $45 \%$ of the total score and was broken down into the following categories and their weightings: geology, $5 \%$; slope, $2.5 \%$; distance to electric Lie-in, 10\%; distance to steam tie-in and consumer, 25\%; steam-line exposure, $10 \%$; distance to water supply tie-in, $25 \%$; distance to rail line, $10 \%$; distance to gas line, $2.5 \%$; and distance to roads, $10 \%$. Several key assumptions were introduced at the study's outset to simplify the evaluation of site utilities. First, all utilities are assumed to be delivered "at the fence" of the facility. This will result in a score that reflects higher interconnect cost to the government if, for example, the RPF is privately constructed and operated. The siting team concluded that all interconnect distances should be treated conservatively, given the magnitude of costs potentially involved. Secondly, parallel use of existing steam, electric, and road corridors was assumed. This approach can minimize clearing and ground-preparation costs as well as reduce environmental impacts. An existing $115-\mathrm{Kv}$ corridor may be expanded to include buried Reactor Cooling System (RCS) water lines and abovegrade steam lines, for example, at substantial cost savings.

All interconnect distances were scaled directly from the 1987 SRS quandrant map at $1: 48,000$ scale with no allowance for topography (Figure 3). Final scores were calculated by normalizing all scores with the maximum score in each category and multiplying this result by the respective category weight. Site scores are proportional to overall interconnection costs with a higher score implying lower cost in general.

Raw scores (Appendix Table B-2) for engineering factors were based primarily on distances from candidate sites to utility service interconnections. Weightings of these factors (Table 1) were primarily based on relative unit (e.g., per 
Replacement Power Facility Site Selection Report

Table 1. Criteria Scores by Site

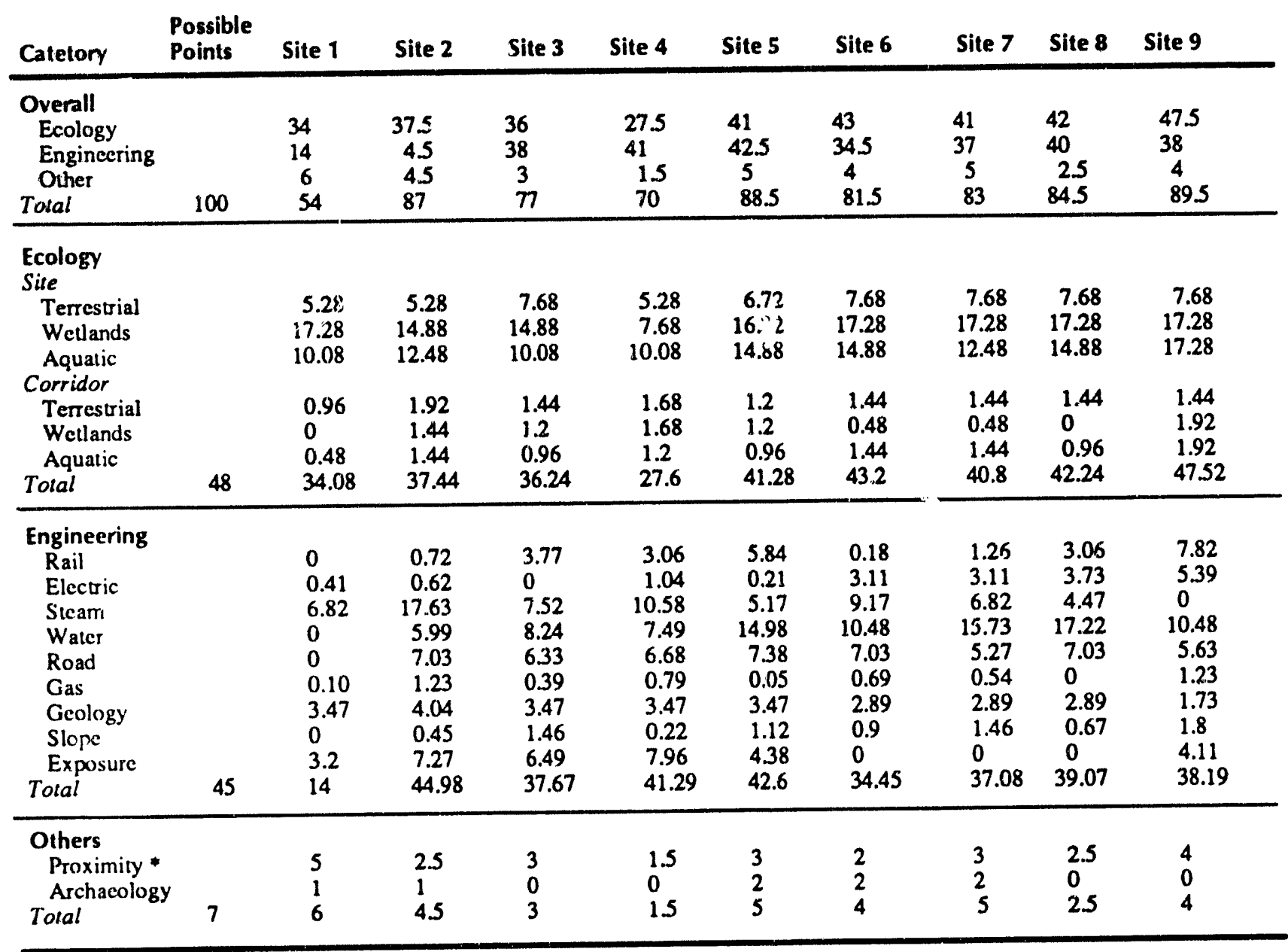

* proximity to existing nuclear facilities 
Figure 3. Candidate Sites and Potentiai Ütiiity Interconneci Cur riườrs 


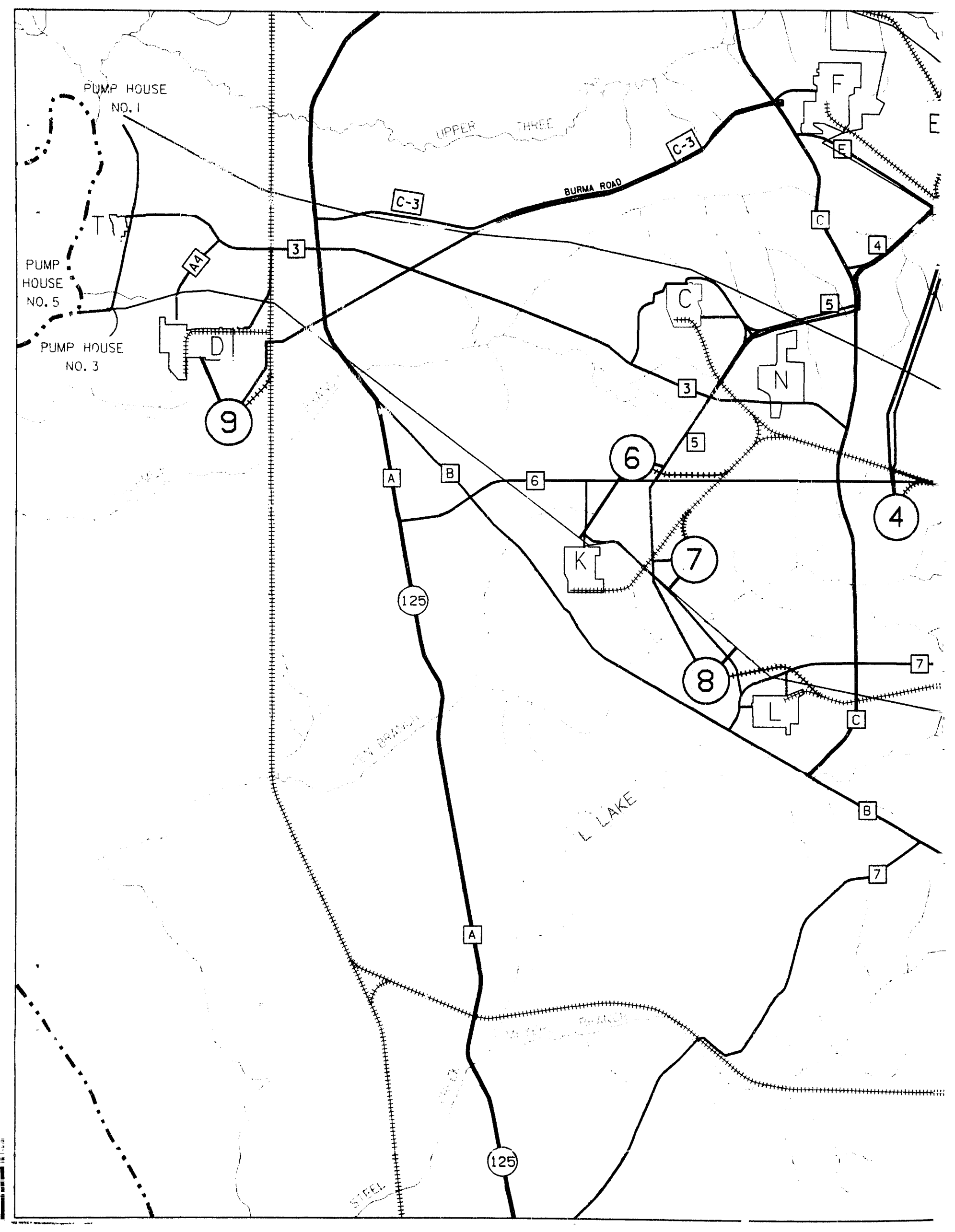




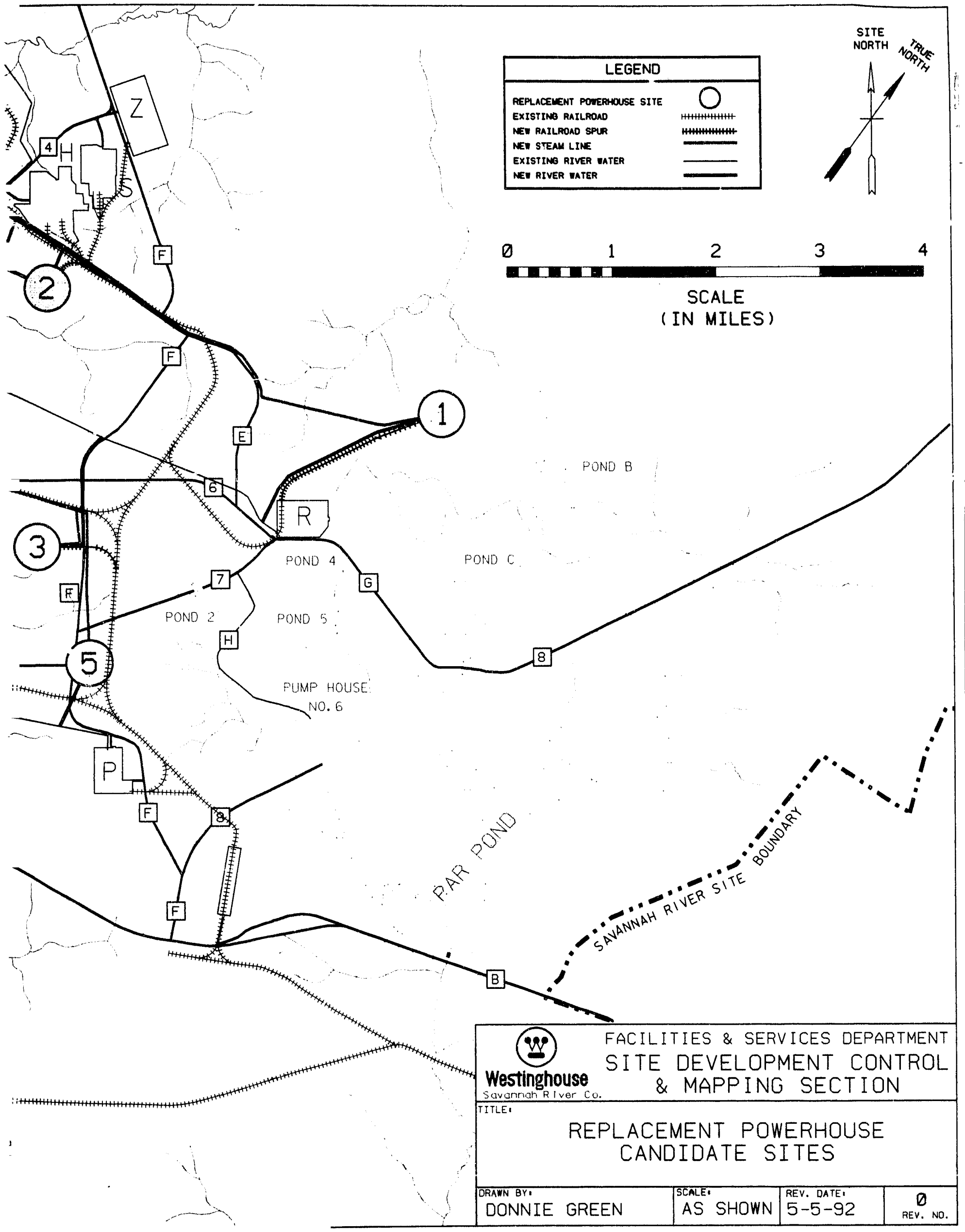


mile) costs of the services. Consequently, raw scores for all factors other than geology reflect inverse indications of favorability (i.e., higher scores are less favorable). Raw scores were processed by first normalizing the matrix such that the highest score for each factor equaled one, and factor scores were multiplied by the factor weight. Where necessary, the scores were then inverted by subtracting each factor score from the highest score so that higher scores represented more favorable conditions. Finally, the entire scoring matrix was rescaled such that the nighest site score equaled 45 , the weight assigned to the engineering category.

Relative scoring of each candidate site, from the standpoint of delivering utility products or suitability for construction, was basid on nine criteria:

\section{Distance to CSX Rail Line}

Rail-line scores measure total distance from the Dunbarton railyard (Figure 3) to the site center for all sites except Site 9. Based on discussions with Central Serv: as and Works Enginecring (CSWE), the siting team $2 \ldots n_{i} \cdots$ ? that use of large-unit trains will require substantial upyrades to SRS track as well as construction of new spur lines. Therefore, all rail lincs beyond the CSX railhead were inviuded.

Corridor width-100 feet

Cost per mile- $\$ 1.0$ million

\section{Distance to Electric Substations}

Electric-line scores measure the total distance from the site center to cither $115-\mathrm{Kv}$ substations 51,52 , or 53 (Figure 3). This configuration provides a highly reliable and flexible switching path to the SRS grid. Each site must be interconnected by a parallel $115-\mathrm{Kv}$ circuit to the nearest SRS line in order to provide normal loopflow at the powerhouse.

Corridor width-150 feet

Cost per mile-\$1.1 million

\section{Distance to $\mathrm{H}$ - and F-Area Steam Line}

Steam-line scores measure the total distance from the site center to the junction of Roads $E$ and 4 except for site 9 , which is assumed to use D Area's existing steam line along Burmia Road. New interconnections to the existing 24-inch, 325-psi H- and F-Area line or D- and F-Area lines will require extensive valving and other flow-control components. All lines are assumed to be above grade.

Corridor width-100 feet

Cost per mile $-\$ 2.4$ million

\section{Distance to Reactor Cooling System (RCS)}

Water-line scores measure the total distance from the site center to adjacent RCS lines. For sites 1, 2, 3, and 4, R-Normal was assumed to be the vperable tap; for Site 5, P-Normal; for Sites 6, 7, and 8, L-Normal; for Site 9, the existing D-Area line to pumphouse 681-3.

Corridor width -100 feet

Cost per mile- $\$ 2.8$ million

\section{Distance to SRS Paved Road}

Road scores measure the total distance from the site center to the nearest, paved two-lane primary road designed to carry moderate construction traffic.

Corridor width - NA

Cost per mile-\$1.3 million

\section{Distance to Jackson, SC, Gas Termination}

Gas-line scores measure the total distance from the site center to a 6 -inch line termination located at the junction of Roads $C$ and 4 except for site 9 , which is assumed to be fed from a termination on Highway 125.

\section{Geologic Factors}

Rating of site geologic factors was based on two geologic parameters, load-bearing properties, and the probability of subsurface carbonate formations. Each site was evaluated by ESS Geotechnical personnel for its suitability relative to the other sites for these parameters. Each site was given a rating based on a composite of the two criteria scores.

\section{Slope}

Sites were comparatively evaluated for slope by visual inspection of maps from the SRS soil survey (Rogers, 1990) and the percent slope of the majority of the site determined. The nine sites were then ranked according to desirability based on the values recorded from the maps. 


\section{Exposure of Steam Line}

The potential reliability impact of routing steam lines along variou road corridors is measured by this criterion. "Exposure" equals the quantity (distance $x$ peak-hour traffic flow) summed over all line segments. Traffic-flow estimates are based on a year 2000 analysis provided to CSWE by Wilbur Smith Associates (1991). It should be noted that the significance of losing steam flow within $F$ and $\mathrm{H}$ areas is not a siting dependent "ariable because this does not depend primarily on the actual RPF site.

The remaining $7 \%$ of the total score was allorated to two criteria categorized as others. The criteria were proximity to existing nuclear facilities, 5 points; and archaeology, 2 points. Archaeology scores were based on the relative portions of the site occurring in sensitivity zones 2 and 3 as determined from archaeological-sensitivity maps (Brooks et al., 1989). It is recommended that comprehensive surveys not be undertaken until preliminary siting concurrence is reached and onsite evaluations are begun.

Proximity to existing nuclear facilities was given equal weight between two factors, likelihood of evacuation (2.5 points) and distance from existing facilities (2.5 points). These criteria address the sites' relative values for security of existing nuclear facilities and RPF-worker safety in the event of releases from operating facilities. The map distance from each site to each of the existing nuclear facilities (General Separations Area [GSA], R, P, L, K, and $C$ reactors) was measured and normalized to a maximum value of one among sites for each area. A score for each site for proximity to each area was calculated by mul.iplying the normalized values by one sixth of 2.5 points. These values were summed by site to provide an overall value for the proximity to existing nuclear facilities for each site. Likelihood of evacuation was calculated the same way except that only the distances from K Reactor and the GSA were used because these are the only existing facilities expected to be operating in the near future. The normalized values were multiplied by 1.25 instead of one-sixth of 2.5 . Active facilities pose the highest likelihood for evacuation, which logically mandates the use of only the GSA and $\mathrm{K}$ Reactor. Scores for likelihood of evacuation and distance from existing facilities were summed by site to provide the score for proximity to existing nuclear facilities.

\section{Additional Concerns}

Additional concerns deals with issues that may be of importance to the siting or operation of the facility and are not discriminated in the selection of sites. These concerns are addressed in the following sections.

\section{Air Quality}

Air quality was not considered in the candidate site scoring, but air-quality modeling must be conducted to support the NEPA action and possible permitting actions. All of the Augusta-Aiken Interstate Air Quality Control Region (AQCR), which includes SRS, attains the National Ambient Air Quality Standards (NAAQS). In addition, the AugustaAiken AQCR is classified as a Class II area under the federal prevention of significant deterioration (PSD) regulations. Class II PSD areas are considered capable of supporting moderate industrial growth. No areas within a 50-mile radius of the proposed sites have been assigned the more restrictive Class I PSD designation.

There are no apparent constraints on local air quality that could adversely affect the permitting of such a powerhouse facility at any of the nine candidate sites. However, this conclusion is contingent on emission offsets from the existing D-Area Powerhouse and a facility design that incorporates appropriate controls on emissions of both "criteria" and toxic air-pollutants as required by the Clean Air Act and South Carolina regulations.

Specific air-quality constraints for toxic pollutants, as regulated by the South Carolina Department of Health and Environmental Control, cannot be determined until potential emissions are identified, and the ambient impacts of these emissions are evaluated by dispersion modeling. Candidate sites closest to the SRS boundary (Sites 1 and 9) are more likely to be affected by the requirements related to toxic air-pollutants.

\section{Pen Branch Fault}

Proximity to the Pen Branch Fault was not quantitatively evaluated in the site selection process because the RPF will be classified as a general use facility requiring minimal seismic design under DOE Order 6430.1.

\section{Movement of Unit Coal Trains Across SRS Roads}

Movement of coal trains may present an obstacle to emergency evacuation of SRS. Several approaches could be used to resolve this concern. One solution could be the construction of railroad over- or underpasses at key highway crossings. This would avoid congestion of major evacuation routes and allow the RPF operator to have primary responsibility the delivery of coal while minimizing DOE's interface and liability. 
As an alternative solution, SRS could accept shipments at the SRS rail-system boundary. The control of the train would then be under SRS management while onsite. A site emergency would implement existing controls similar to CSWE procedure DPSOP 301 (section 5), which specifically requires the decoupling of fuel trains that block intersections.

\section{Results}

Each sitc was evaluated for each criterion within each category and awarded scores. Higher scores indicate favorability for location of the RPF. For example, a site near a pristine headwater stream would receive a lower score in the aquatic-resource criterion of the ecology category than a site with no unimpacted streams near by.

Ecology ratings rank the sites in order of increasing desirability as the following: $4,1,3,2,5,7,8,6$, and 9 (Table 1). Site 4's low rating was not a result of an exceptionally poor rating in any individual category but results from a generally poor rating in most criteria. Site 1, however, was substantially poorer than the other sites in its corridor ratings. S 3 and 2 are essentially equivalent, as are sitcs $5,6,7$, ard 8 . Site 9 is the highest ranked site in terms of ecological acceptability, losing only half a point from the possible total of 48 , although it is not substantially better than sites $5,6,7$, and 8 .

Enginecring ranking arranges the sites in order of increasing acceptability as $1,6,7,3,9,8,4,5$, and 2 (Table 1). Site 1 is significantly less areptable than all others.

The others category (Table 1) ranks the sites as 4, 8, 3, 6, 9, $2,5,7$, and 1 in increasing order of desirability.

The total scores for each site are shown in Table 1. The sites are ranked in the following order from most to least desirable: $9,5,2,8,7,6,3,4$, and 1 .

\section{Conclusions}

Figurc 4 shows the total scores grouped by five-point intervals. This figure makes it clear that there are no large differences between the best six sites, 2, 5, 6, 7, 8, and 9 . Obviously, there is almost no difference between Sites 2, 5, and 9 . Based on the total scores, there is a spread of only two and $a$ half points between them. Sites 5 and 9 are essentially equivalent, differing by only a half point (Table 1 ) and would therefore be equally suited to the RPF.
100

90

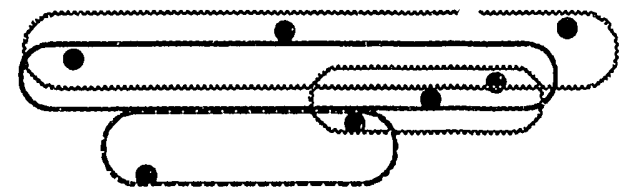

Score

70

60

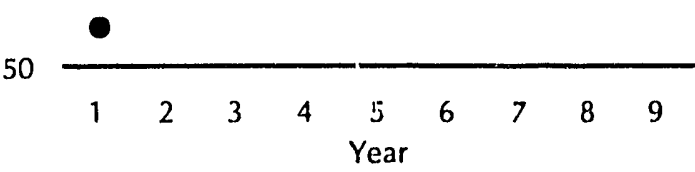

Figure 4. Grouping of Site Total Scores by Five Point Range

As this report is required to recommend a single site, an effort to differentiate between Sites 5 and 9 was made. The 17 decision criteria were sorted by weight and the site scores plotted against them to illustrate any differences in "robustness" between the sites. Robustness in this sense would be greater for a site scoring consistently higher in the most heavily weighted criteria.

Figure 5 compares scores of the two sites. All 17 decision criteria are plotted along the vertical axis with the highest weighted scores appearing at the bottom. The six most heavily weighted criteria capture nearly $70 \%$ of the study's total decision weight. Comparison of the sites indicates that Site 5 captured consistently higher scores among the highest criteria than Site 9. In addition, Site 5 outperformed Site 9 in some lower weighted but significant criteria such as roads, geology, and archaeology.

As seen in Figure 6, the average standardized score for Site 5 (0.95) is higher than that of Site $9(0.77)$ when scores of the two sites are siandardized to each other (lowest divided by highest) and plotted against criteria sorted by weight ( $Y$ axis, from highest to lowest), even though each site has three highest scores in the six highest-weighted criteria. Although the mean standardized scores for both sites for all criteria are similar, the performance of Site 5 in the six criteria that account for $70 \%$ of total score shows this site to be more robust. 
Site 9

Site 5

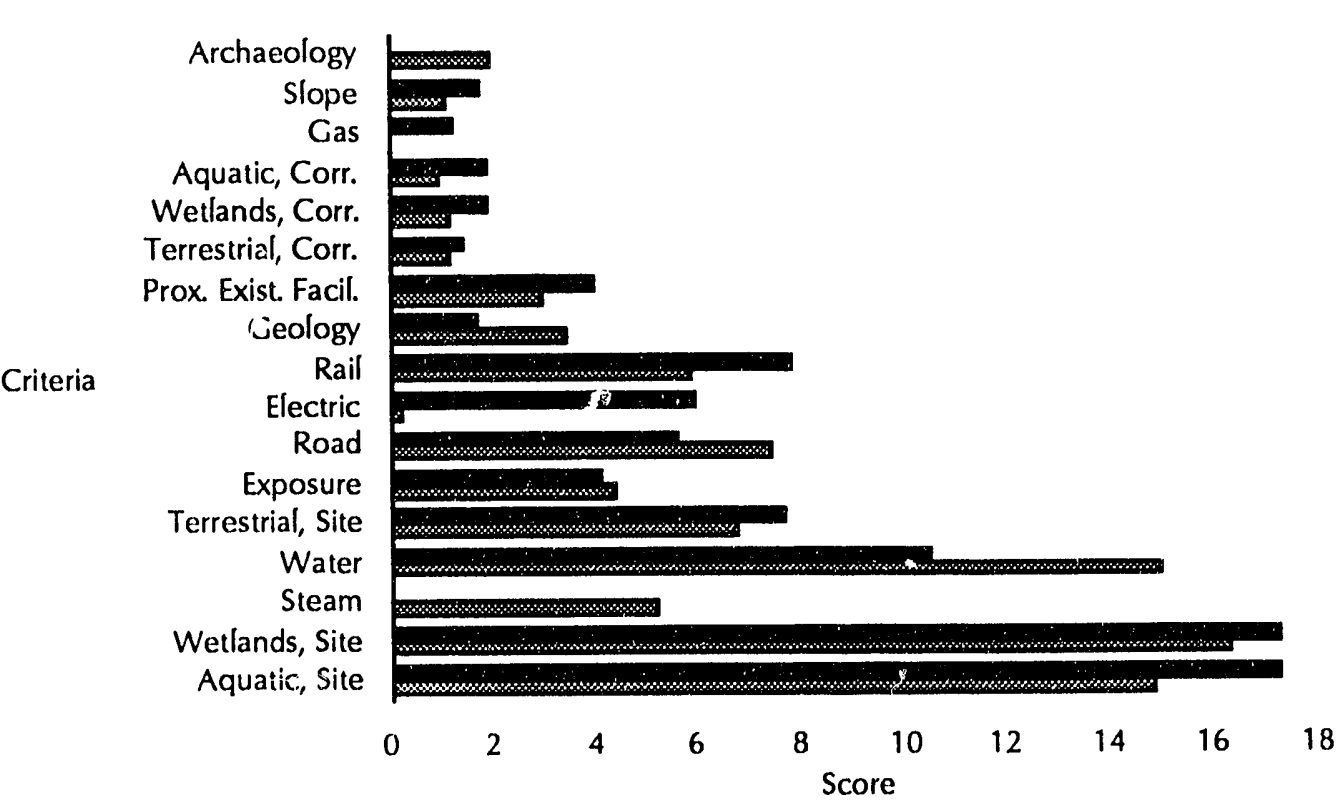

Figure 5. Site Criteria Scores Sorted by Weight

1.0

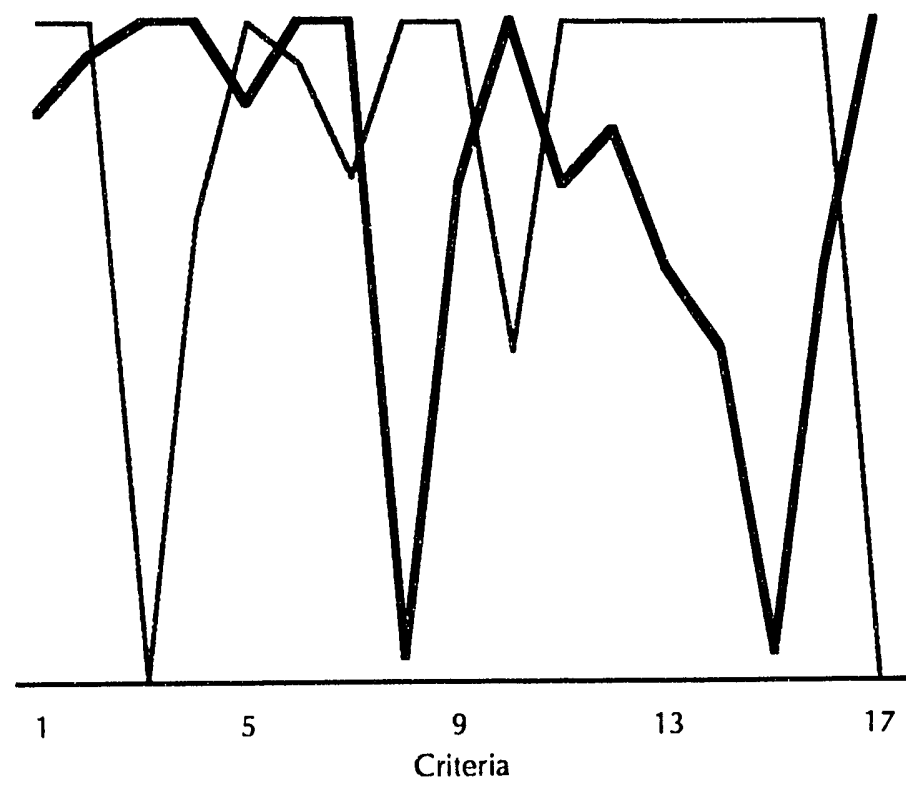

Figure 6. Standardized Site Criteria Scores Sorted by Weight 


\section{Recommendation}

Based on the robustness analysis as the only differentiation between Sites 5 and 9, Site 5 is recommended as the preferred site and Site 9 as the alternate site for the RPF. It is, however, the recommendation of this report that Sites 5 and 9 both be characterized in greater detail as the next step in the siting process. This process of analyzing both sites will allow greater latitude and flexibility in locating the facility should any unforeseen difficulties arise with the preferred site during detailed characterization.

\section{Acknowledgments}

The site-sclection team wishes to gratefully acknowledge the assistance of Dave Isiminger and Donny Green of the Facilities and Services Department of the Site Services Division for their enthusiastic support and excellent maps. The team also wishes to acknowledge the editorial support provided by Marc McConathy of the Technical Publications Group of the Management Information Services Section.

\section{References}

Brooks, R. D., Brooks, M. J., Hanson, G. T., Sassman, K. E., Lew/is, G. S. Archaeological Resource Management Plan of the Savannah River Archaeological Research Program. (1989)

DOI (U.S. Department of the Interior). U.S. Fish and Wildlife Service Mitigation Policy, 84 ESM 2, Chapter 2. (1981).

Ebasco Services, Inc. Draft. Westinghouse Savannah River Company Replacement Power Facility, Task 029 Capital and Life Cycle Cost Estimate. (March 1992).

Hillestad, H. O., Bennett, S. H., Jr. Set-aside Areas National Environmental Research Park Savannah River Plant Aiken, South Carolina. SRO-819-11. Savannah River Ecolngy Laboratory, Aiken, SC. (1982)

Rogers, V. A. Soil Survey of Savannah River Plant Area, parts of Aiken, Barnwell, and Allendale Counties, South Carolina. USDA Soil Conservation Service. (1991).

Wilber Smith Associates, Area and Plant Traffic Distribltion Study, Post-2000. (1991). 
APPENDIX A 


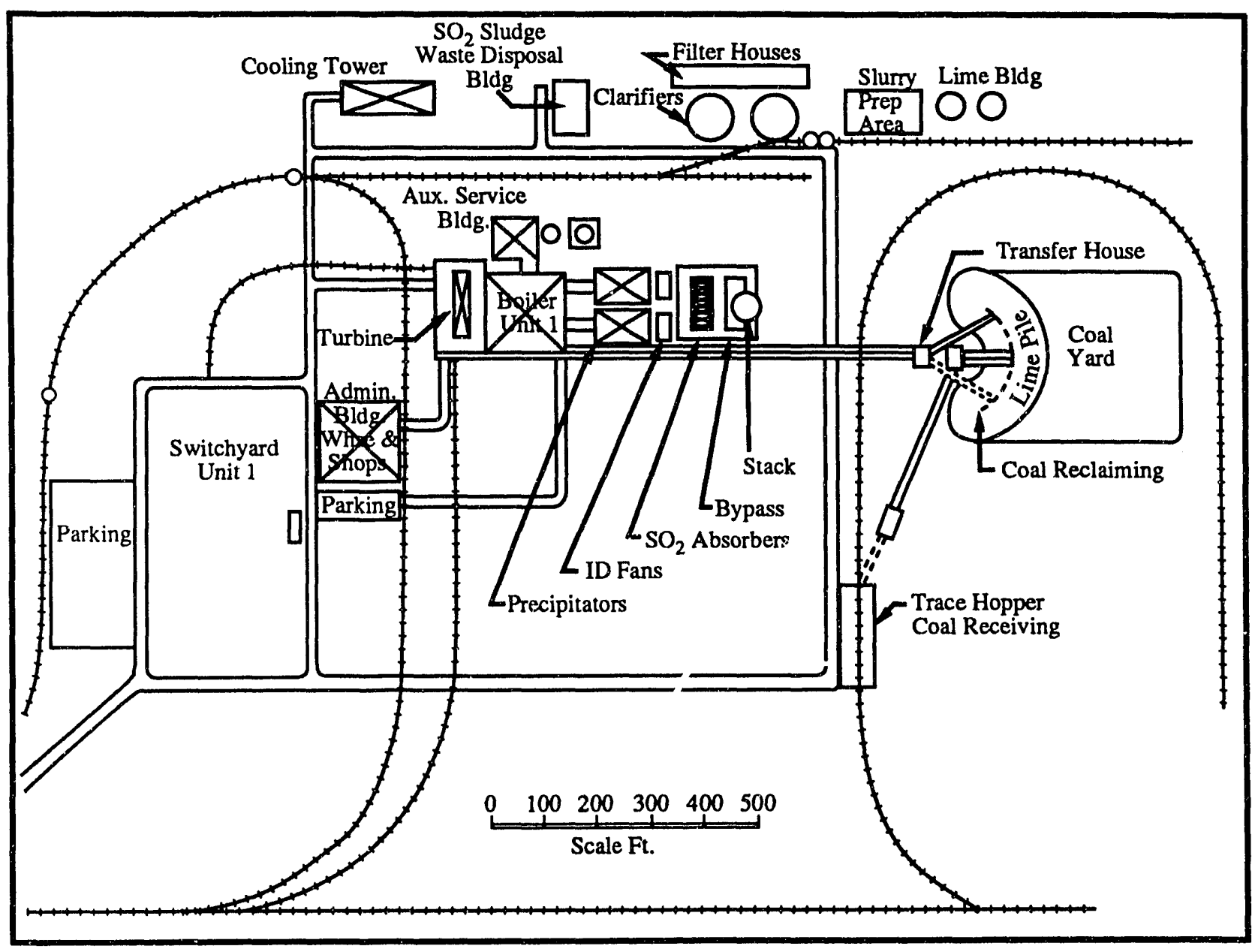

M92F014

Figure A1. Generic Powerplant Layout 


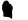

APPENDIX B 
Table B1. Raw Scores by Site

\begin{tabular}{|c|c|c|c|c|c|c|c|c|c|}
\hline Catetory & Site 1 & Site 2 & Site 3 & Site 4 & Site 5 & Site 6 & Site 7 & Site 8 & Site 9 \\
\hline \multicolumn{10}{|l|}{$\begin{array}{l}\text { Ecology } \\
\text { Site }\end{array}$} \\
\hline Terrestrial & 11 & 11 & 16 & 11 & 14 & 16 & 16 & 16 & 16 \\
\hline Wetlands & 36 & 31 & 31 & 16 & 34 & 36 & 36 & 36 & 36 \\
\hline Aquatic & 21 & 26 & 21 & 21 & 31 & 31 & 26 & 31 & 36 \\
\hline \multicolumn{10}{|l|}{ Corridor } \\
\hline Terrestrial & 2 & 4 & 3 & 3.5 & 2.5 & 3 & 3 & 3 & 3 \\
\hline Wetlands & 0 & 3 & 2.5 & 3.5 & 2.5 & 1 & 1 & 0 & 4 \\
\hline Aquatic & 1 & 3 & 2 & 2.5 & 2 & 3 & 3 & 2 & 4 \\
\hline \multicolumn{10}{|l|}{ Engineering } \\
\hline Rail & 45 & 41 & 24 & 28 & 12.5 & 44 & 38 & 28 & 15 \\
\hline Electric & 37 & 36 & 39 & 34 & 38 & 24 & 24 & 21 & 13 \\
\hline Steam & 28.5 & 5.5 & 27 & 20.5 & 32 & 23.5 & 28.5 & 33.5 & 43 \\
\hline Water & 13.5 & 9.5 & 8 & 8.5 & 3.5 & 6.5 & 3 & 2 & 6.5 \\
\hline Road & 11.5 & 1.5 & 2.5 & 2 & 1 & 1.5 & 4 & 1.5 & 3.5 \\
\hline Gas & 39 & 16 & 33 & 25 & 40 & 27 & 30 & 41 & 16 \\
\hline Geology & 3 & 3.5 & 3 & 3 & 3 & 2.5 & 2.5 & 2.5 & 1.5 \\
\hline Slope & 9 & 7 & 2.5 & 8 & 4 & 5 & 2.5 & 6 & 1 \\
\hline Exposure & 9.6 & 1.6 & 3.15 & 0.26 & 7.3 & 15.9 & 15.9 & 15.9 & 7.82 \\
\hline \multicolumn{10}{|l|}{ Total Cost in } \\
\hline$\$$ millions & 32.537 & 18.268 & 23.368 & 20.484 & 20.772 & 23.140 & 23.687 & 20.001 & 19.844 \\
\hline
\end{tabular}

* proximity to existing nuclear facilities 

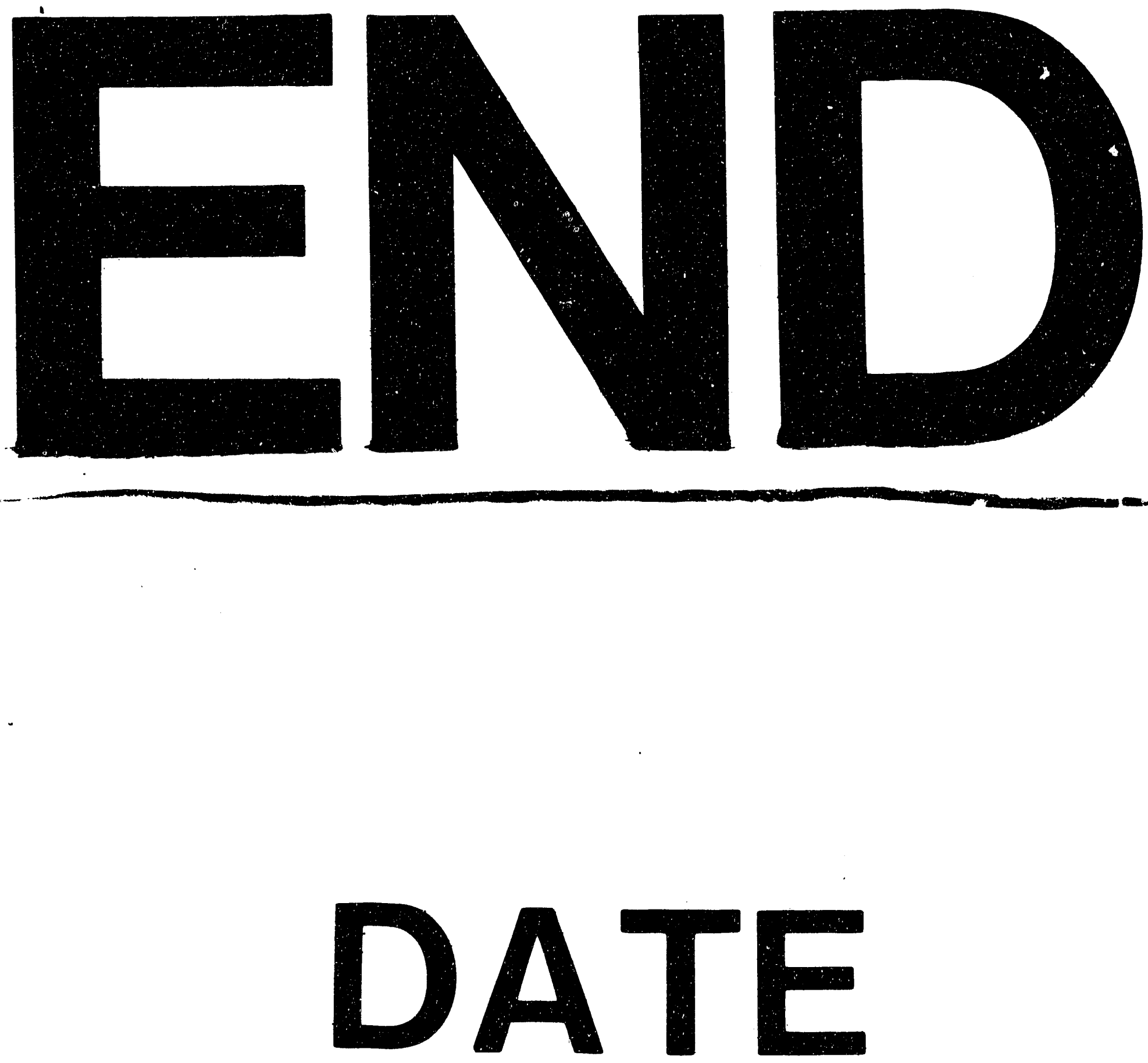


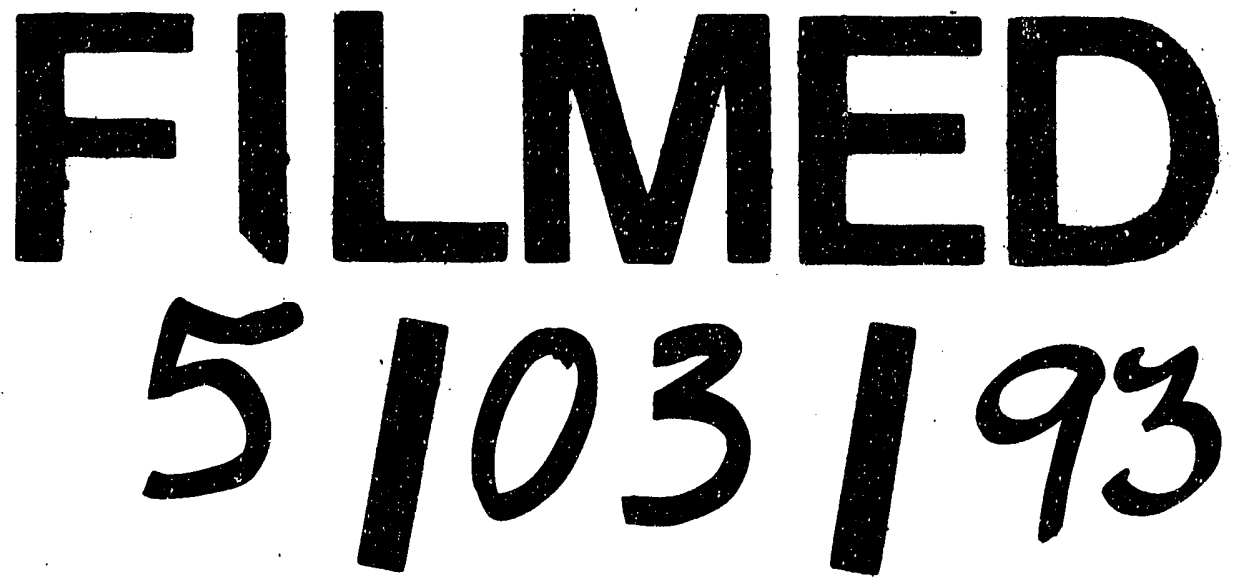